This item was submitted to Loughborough's Research Repository by the author.

Items in Figshare are protected by copyright, with all rights reserved, unless otherwise indicated.

\title{
A case study of Intra-EU Migration: 20 Years of 'Brits' in the Pays d'Auge, Normandy, France
}

PLEASE CITE THE PUBLISHED VERSION

http://dx.doi.org/10.1057/fp.2008.11

PUBLISHER

(C) Palgrave Macmillan

VERSION

AM (Accepted Manuscript)

\section{PUBLISHER STATEMENT}

This work is made available according to the conditions of the Creative Commons Attribution-NonCommercialNoDerivatives 4.0 International (CC BY-NC-ND 4.0) licence. Full details of this licence are available at: https://creativecommons.org/licenses/by-nc-nd/4.0/

\section{LICENCE}

CC BY-NC-ND 4.0

\section{REPOSITORY RECORD}

Drake, Helen, and Susan Collard. 2019. "A Case Study of Intra-eu Migration: 20 Years of 'brits' in the Pays D'auge, Normandy , France”. figshare. https://hdl.handle.net/2134/15854. 


\title{
A Case Study of Intra-EU migration. 20 Years of 'Brits' in the Pays d'Auge, Normandy, France Helen Drake and Susan Collard
}

\author{
Helen Drake, Senior Lecturer in French and European Studies \\ PIRES (Politics) Department \\ Loughborough University \\ LEICS. LE11 3TU, UK \\ Tel: 00441509222989 \\ Fax: 00441509223917 \\ h.p.drake@lboro.ac.uk \\ Susan Collard, Lecturer in French, \\ Sussex European Institute \\ University of Sussex \\ Falmer \\ BRIGHTON BN1 9RG \\ Tel: 01273678578 \\ Fax: 01273678571 \\ s.p.collard@sussex.ac.uk
}

\begin{abstract}
Britons are owning property and living in France like never before. As such, they are part of the broader phenomena of the free movement of European Union (EU) 'citizens' within the EU's borders (intra-EU migration); and the centuries-old Franco-British relationship. We explore the salience of each of these contexts for the latest British emigrés to cross the Channel, by means of a case study of the Pays d'Auge area of Normandy. On the basis of our fieldwork with approximately 20 British households, we assess and update material first collected from and about these British migrants almost two decades ago. We review our findings in the light of the state of the FrancoBritish relationship, and the realities of a 'Citizens' Europe'.
\end{abstract}




\section{A People's Europe? Free-moving EU "Citizens" at Large}

European integration has always been and remains a question of bringing people and peoples closer together, literally and metaphorically. In this article, we assess the significance of recent waves of British migration to France from this perspective. Britons have been enthusiastically touring France, ecaping, vacationing and settling there for centuries; here, we want to ascertain what difference, if any at all, EU provisions for 'citizenship' make to these migrants' stories, especially in comparison to other factors, including those pertaining specifically to the Franco-British relationship.

In terms of the freedom of movement, there were 'citizens' before the Maastricht Treaty created the EU and the 'European citizen' as a formal and legal entity, and our study in fact concerns a sample of Britons who emigrated to France at the tail end of Thatcher's decade - the 1980s. Nearly twenty years after their exodus, they offer us their reflections, and we reflect upon the extent to which their status as EU 'insiders' is incidental to more compelling and age-old logics motivating the migratory decision. The original four freedoms of the Treaty of Rome included the freedom of movement of 'persons' as workers, and in 1992, the Maastricht Treaty on European Union went so far as to create the legally-enforceable figure of the European Citizen who is steadily accruing rights, expectations and, who knows, identity. These advantages include the right to mobility and residence within the $\mathrm{EU}$, the right to vote and stand for election at local and EU-level elections in the member state where they are resident; and access to social rights in the form of, for example, welfare and education provision. Of these, Recchi insists on the 
significance of 'the rights to free movement and settlement in the entire EU territory' as the 'cornerstone' of EU citizenship' (2006: 60). In these ways, Europeans are reminded of their role as actors in the integration process, above and beyond the commodification of their functions as consumers, tourists, students, pensioners or workers, and this in increasingly glaring contrast to the EU's 'outsiders', or third country nationals (TCNs).

Indeed, one aspect of this people's Europe is that the movement of people with an intent to settle or reside, either temporarily or permanently, based on a desire for change, increasingly occurs in a public policy environment dominated by discourses of immigration and asylum and in a specific international situation in which the EU's leaders perceive themselves to be operating. ${ }^{1}$ This is a policy frame focused on the world outside the EU's boundaries and on movement from that world towards the EU in the form of breaches, potential and actual, of the EU's frontiers. The emphasis thus, is increasingly on immigrants rather than on migrants in the form of EU nationals; the EU's 2004 directive ${ }^{2}$ concerning intra-EU migration is nevertheless intended to 'encourage [all] Union citizens to exercise their right to move and reside freely within the Member States' and to harmonise such matters across the EU.

On certain occasions, intra-EU movements have themselves generated considerable media, political and public attention, especially where so-called

\footnotetext{
${ }^{1}$ Thus the UK government's 2005 policy document entitled Controlling our borders: making migration work for Britain' was more accurately sub-titled Five year strategy for asylum and immigration (our emphasis; HM Government (2005)

${ }^{2}$ European Parliament and Council Directive 2004/38/EC of 29 April 2004 on the right of citizens of the Union and their family members to move and reside freely within the territory of the Member States. http://europa.eu/scadplus/leg/en/lvb//33152.htm
} 
economic migrants are concerned. In the case of the 2004 EU enlargement, for example, this very aspect of enlargement became a significant nuisance for the French government in its doomed battle to persuade the French population to ratify the EU's Constitutional Treaty. An unexpected figure emerged mid-way through the referendum debates; namely, the 'Polish plumber', an imaginary and notional character later held partly responsible for the sinking of the Treaty.

In the highly specific context of the then imminent liberalisation of the EU's market in services via the Bolkestein Directive, the spectre of the Polish plumber arriving to undermine French servicemen and women by his cheap labour and sub-standard workmanship was manipulated by opponents of the treaty to symbolise all that was deemed wrong with it, and in particular its provisions for economic and social policy characterised as a step too far towards an Anglo-Saxon free-market scrum. French President Sarkozy has sought to make political capital out of such perceptions by promoting a 'Europe that protects [its citizens]', while simultaneously setting out to reform the French labour market along more 'Anglo-Saxon' lines. France, moreover, was amongst the large majority of EU member states who took advantage of the right temporarily to restrict the entry of migrant labour from the central and east European EU member states in both 2004 and $2007 .^{3}$ Far more numerous and stealthy were the numbers (notoriously hard to quantify) of Britons emigrating across the Channel, many to work - as we see below; and

\footnotetext{
${ }^{3}$ In its 2005 report, the French Department for Population and Migrations reported that it was using the 5-year transitional period from 1 May 2004 to work on its relations with the EU8. At the March 2006 ' +2 ' decision point, the French fell into the category of those EU15 member states planning gradually to lift the transitional measures over the following 3-year period in specific relation to sectors suffering labour shortages; the same measures were applied in the case of Bulgaria and Romania in 2007.
} 
the rising numbers of French nationals leaving France to work in Britain, an anomaly in a country with little modern history of emigration.

\section{The Franco-British Relationship on the Move?}

Indeed, one of the more benign novelties of the 2007 French presidential campaign was the brief appearance of presidential candidate Nicolas Sarkozy in London in late January 2007. This was his first mass rally, and the first of his campaign visits overseas. All charm and bonhomie, his mission was apparently to coax his fellow French men and women home, or at least to invite them to think about it. Favell (2008) identifies London as a 'Eurocity', home to hundreds and thousands of 'Eurostars', including from France (2005). ${ }^{4}$ Sarkozy's charm offensive was very specific in character: under 'the value of work' banner, he concerned himself with the opportunity cost for the French economy of the brain and train-drain, the exodus of dynamic young hopefuls to London, courtesy of Eurostar. Sarkozy urged these fellow French men and women to return: 'to all those who have gone abroad and are unhappy about the situation in France and having left it, I want to say "Come back!". Come back and you will see that with a little energy, courage and will our old country can again do great things.' These expatriates were also, of course, potential voters and supporters of his campaign for the presidency.

\footnotetext{
${ }^{4}$ The Guardian 30/03/07, p. 14 reported between 200,000 and 300,000 French people living in Britain: 'With an average age of 29 most are part of a brain drain from France's universities and many work in the City.' Yet if anecdotal and observational evidence is anything to go by, considerable numbers of them are also in the sort of McJobs apparently reviled in France.
} 
Even allowing for the hype of this particular media stunt, Sarkozy's initiative is instructive in that it alludes in relatively explicit terms to the commonplace notion that France and Britain are polar opposites in terms of so-called 'models' of capitalism. The terminology of the 'Anglo-Saxon' free market economy is hard currency in French political discourse and, in so far as migrants and expatriates collectively hold up a mirror to the society they have left behind, Sarkozy's address to the London-based French functioned for the candidate as a platform for his mild critique of his homeland in comparison to the dynamism of the London job scene as he perceived it. Is it this aspect of the urban scene that Britons are seeking to escape? Could France be for sale, a property mecca, while the French are for hire? Is the rush of Britons to France in the chassécroisé of cross-Channel migration an example of a universal human drive for self-improvement and material gain? An exercise of citizenship rights; or the most recent expression of a centuries-old Franco-British affinity?

Tombs (2006: 654) note that 'residence, not tourism, is the real novelty' of the 'unprecedented cross-Channel migration' that took place towards the end of the $20^{\text {th }}$ century, although they remind us that it is not the first time that rural France has been 'the recipient of a unique devotion going well beyond considerations of price, convenience and weather', referring here to the nineteenth century (656). The English, after all, 'made the Alps' (Ring, 2000; see also Geoffroy, 2007 and for a general overview, Campos, 2004). The difference in the 1990s migratory experience was the rush to purchase property, where previous occupants had rented, 
and that 'modern British settlers, unlike their forerunners, yearned to be accepted by the locals.' (657)

\section{Motivations and intentions: from would-be to actual migrants}

Most of the existing published knowledge about the 'Brits' in France has focused on the motivations and intentions of the migrants themselves, in the form of decisions taken at the level of the individual (or individual household), determined by many factors relating to the identity of the migrant him/herself, such as age, sex, profession and so on. These studies express caution regarding the numbers involved: counting migrants is notoriously difficult, given the lack of sanctions and incentives for non-registration (a comment itself on the realities of EU citizenship), and the sometimes transitory existence of migration, particularly when it fails and the migrants return.

Gervais-Aguer (2006), citing the provisional results of the 2004 French rolling census, gives the number of permanently resident Britons in France as around 130,000 , with an new increase in flows since 1999. Sriskandarajah and Drew, in contrast, estimated at 200,000 the 'stock' of British people living in France in 2006; their method was 'sensible' triangulation: 'combining multiple methods and different data sources' (2006: 17). Labie (2004 2) offers figures for 1990 which put the total number of British residents in France at $0.10 \%$ of the total population, including those Britons having taken French nationality. By 1999 , this figure had risen moderately to $0.13 \%$, but in absolute terms the numbers had increased by $50.8 \%$, from 25,440 to 75,546 British people. The preferred destinations of these additional UK migrants had, moreover, continued to concentrate in the south west of France, but also 
included Brittany and Normandy. Labie (2004) counted those migrants who had registered on electoral lists (a rise of $11 \%$ in absolute terms in the whole between 1999 and 2001, when 12,428 British residents registered of France); and the number of residency permits (cartes de séjour) issued, a measure which mainly demonstrated to her the drift of the later British arrivals to the north of the region. ${ }^{5}$

More concrete than numbers, paradoxically, are the findings regarding motivations, intentions and expectations, where we might have expected illusions if not delusionary thinking. Buller and Hoggart (1994) and Barou \& Prado (1995), were amongst the first researchers to address these questions, with Gervais-Aguer (2004, 2007), Benson (2007), Labie (2004), Smallwood (2007) and Puzzo (2007) amongst those who turned their attention to the $21^{\text {st }}$ century British migrants to settle in rural France. Gervais-Aguer $(2004 ; 2007)$ demonstrates that in the case of both would-be and actual migrants, the pull of the new lifestyle, imagined or real, dominates all other factors behind the decision to migrate; these migrants are what Crawford (2007), in the Spanish example, dubs the 'lifestyle exiles. ${ }^{, 6}$ The decision to migrate is by and large driven by 'hedonic' considerations relating to the anticipated quality of life in France; these considerations may relate more or less specifically to expectations regarding 'amenities like the climate, the physical and social environment and any public goods and services at agents' disposition locally

\footnotetext{
${ }^{5}$ But we note here that the carte de séjour criterion is of severely limited use as a measure of intra-EU migrant numbers, simply because the practice of requesting and demanding it had already largely fallen into disuse before it was formally abandoned by the government in November 2003.

${ }^{6}$ O'Reilly (2002) and King et al (2000) are unmissable references in the case of British expatriation to Spain. Direct comparisons of the 'Brits' in their various migration destinations in Europe lie outside the scope of this article, however.
} 
(Gervais-Aguer, 2006: 8); or to 'a site's attractiveness' in terms of the quality and quantity of work on offer.

Here the distinction between rural and urban lives is important. The clear majority of the research on Britons in France relates to the strong pull of the French rural life specifically conceived of as an escape from the urban congestion of Britain. Barou and Prado (1995) offer a particularly rich analysis of the comparative meanings and significance of 'the rural' in France and the UK as the foundation for their study of 'The English in our Countryside' (which provides the initial data on our case-study sample below). Similarly, Benson (2007) offers insights into how British migrants to the Lot in France conceive of the 'authenticity' of their new, rural lives in comparison to what they had before.

Indeed, an analysis of the push factors behind Britons' decisions to migrate are particularly instructive in respect of notions of the rural life. Labie (2004), in her study of the British in the Poitou-Charentes region of France tells us that the quality of life - or lack thereof - is what drove most of her respondents away from the UK, especially the congested South East, above and beyond family, financial, political or economic reasons. These lifestyle contrasts, real or imagined, will of course be familiar to those of us au fait with UK media representations of the 'good life' in France, the media being a second, significant push factor (Labie, 2004; Barou \& Prado, 1995: 30). We can link the push of the broadcast media back to the so-called Mayle effect - the fall out on Provence from the publication in 1989 of Peter Mayle's idealised 'Year in Provence' which spawned both actual migration and an accompanying industry of services designed to facilitate the migrant at every 
step of the migration process; thus, the movement of Brits to France has been accompanied by the movement, virtual and real, of solicitors, tax advisors, property managers, estate agents; plus more general magazines and other offerings. These are developments certainly fuelled and facilitated by the Internet and telecommunications technologies; in contrast, the incentive of low-cost flights came surprisingly low down the list of priorities for GervaisAguer' sample of would-be migrants (2006), but were mentioned by Labie's subjects as one reason for the attraction of the Poitou Charentes region of France.

\section{British migrants and their hosts}

These are findings which should cast strong light on the successes and failures, potential and real, of the migrant experience. We note that the term 'integration' could for a researcher be an undesirable source of normative bias; nevertheless, it seems valid to enquire into the extent to which the British incorporate and involve themselves in the lives of their host countries; and whether they avail themselves of any of their rights as EU citizens. Benson's interest (2007) in the quest for the 'authentic' life accentuates the importance for the migrants of the Lot of their distinction from mere tourists ${ }^{7}$; and Tindall (2004: 277 ) raises the possibility that settlement, as opposed to tourism may well despoil the rural idyll sought by the migrant in the first place. This is in strong contrast to the Spanish case where Crawford (2007) observes how many British migrants to the Mediterranean coast of Spain

\footnotetext{
${ }^{7}$ It is the case that British settlement in France, certainly the 'wave' of the late 1980s, tends to begin with tourism, on the basis of which second homes are purchased, which subsequently may lead to to plans for more permanent residence. This certainly was the pattern for the Dordogne region of France. (Gervais-Aguer, 2004; Barou \& Prado, 1995).
} 
prefer to see themselves as 'upmarket tourists' as opposed to residents. We can assume that if most Britons are in France for the authentic, rural experience, this tourist mentality is less likely to travel across the Pyrenées. Integration, however we define it, figures amongst the motivations, in some cases unconscious, of important numbers of UK migrants. The 20 or so semistructured interviews that substantiated her 2004 study led Gervais-Aguer to postulate the existence of three types of UK migrant defined by their level of integration, as they perceived it. The integrated Britons were usually unsurprisingly - Franco-British couples who worked in a French environment; others were poorly-integrated (as in peu - not very), having given up or never sought to integrate, but satisfied with their new lives; finally those who were non-integrated but who wished to be so; they formed a minority of frustrated cases who generally would at some point return to Britain on a strong note of failure.

If we concur with Labie that real - authentic? - integration lies beyond the ballot box every much as in the precious political right to vote, then she (2004: 6) offers interesting observations: viz, a sore lack of formal opportunities for the interaction of the French and the British, her research indicating that language was a most significant factor in the integration process. In particular, she attributed the colonising, 'little Briton' phenomenon associated with the Spanish example to the self-perpetuating and defeatist cycle by which British migrants acknowledge that they are poor at French, that they can get by without it, and that they can therefore live amongst themselves. In some cases this can lead to a sort of internal (possibly black) market amongst the British, ranging from education to building work. Fralon (2006) bases his 
purportedly humorous notion of the 'invasion' of the British on precisely this aspect of the British migrants' lives. Sriskandarajah and Drew (2006: 44), based on their study of the 'Brits' abroad in general, come to the conclusion that the 'major barrier to integration in another country seems to be language'; their and others' studies (eg. as cited by Crawford, 2007) also make the ominous observation that on this score, British migrants (and their children) are particularly poorly-equipped in comparison to other EU migrants.

Integration is not a linear process, and does not proceed at an equal pace at all times; like other cultural shocks, migrants will experience ups, downs and plateaus in their attempts to live their new lives. There may well be incentives on the part of the host authorities, however, to intervene in the process for a variety of reasons. Fralon (2006) refers to the role of French public authorities in encouraging low cost airlines to the south-west of France in order to accelerate the economic benefits that the British migrants would and did bring to the region; and in le Monde (2005) we read of how the council one of the villages in the Dordogne where 'Brits' are most heavily concentrated appointed a bilingual 'Brit' to assist and innovate in the integration process. ${ }^{8}$ On the other hand, Barou and Prado (1995: 147) note how French locals generally do not expect or even want British residents to integrate, but see their efforts positively when they do.

\footnotetext{
${ }^{8}$ This position, we are told, was part-financed by the EU's Leader Plus regional fund.
} 


\section{A Case-Study of British-French migration - the Pays d'Auge,}

\section{Normandy}

The choice of location for this case-study was determined by a coincidental combination of two factors. Barou \& Prado (1995) base one chapter on data collected in 1992 from an area where Collard was able to identify all the individuals concerned by dint of personal circumstances which enabled her arguably to fulfill the anthropologists' criteria for such an ethnographic study. Buller and Hoggart (1994) had also carried out part of their research in roughly the same area (Calvados). It thus seemed appropriate to try to trace the stories of these British migrants, and determine how their experiences had unfolded fifteen years after the original study. ${ }^{9}$

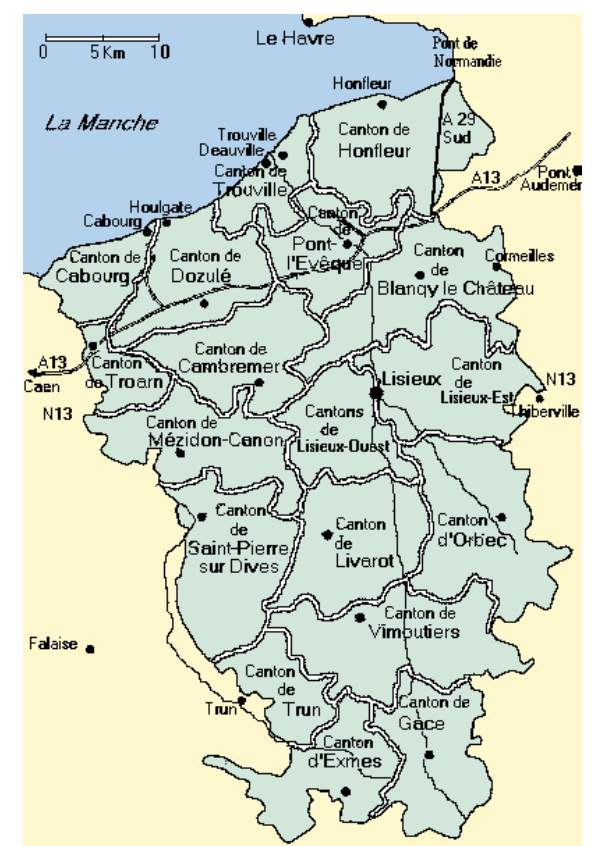

\footnotetext{
${ }^{9}$ The method of enquiry was to conduct individual interviews based on a questionnaire but allowing for free discussion as volunteered by the interviewee, lasting between 45 minutes and three hours each. This work has been carried out with the endorsement of the original author of the chapter, Jacques Barou, who unfortunately has not retained any of the archives relating to the field work, which was carried out by a research assistant. The original interviewees were identified through a combination of 'hints' given in the original text, and personal contacts in the area, and a semi-structured interview was conducted with each individual and/or couple.
} 
The Pays d'Auge is located in Basse-Normandie, and we are concerned in this study with the Southern part of the area, straddling the cantons of Vimoutiers and Livarot. The area is reputed for its cider-making, its cheese (Livarot, Pont l'Evêque, Camembert), its studs, and its gently rolling countryside dotted with distinctive timber-framed houses and cider apple trees. This is the stuff of picture post-cards.

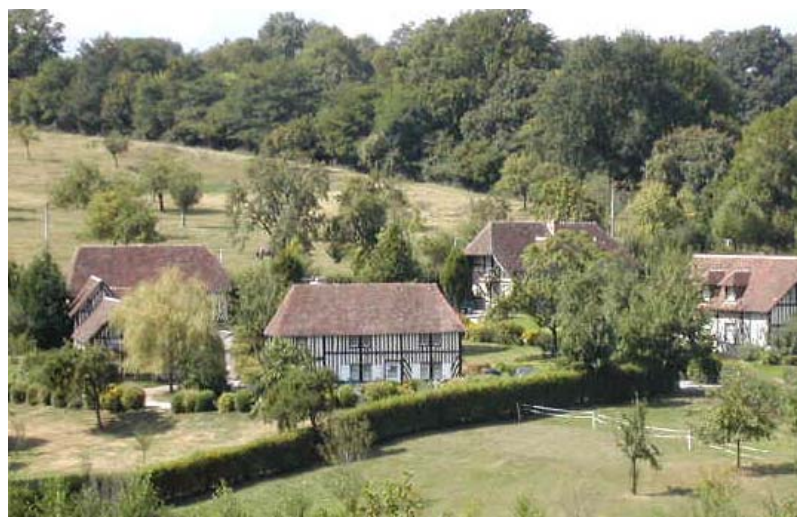

Barou's selection of this area was informed partly by its proximity to the South of England, and by the fact that there was no history of settlement by the British here, unlike in the Dordogne for example; the development of tourism was only recent, the local population was ageing, mainly engaged in dairy farming, more recently forced to diversify, struggling to survive, and over past decades had suffered depopulation, with little exposure to foreigners except of the Parisian kind with second homes. The response to new residents was thus deemed to be of particular interest.

Barou presents the British arrivals as being on the one hand potential saviours of the countryside, by the restoration of the old buildings allowed to fall into ruin by their French owners, the boost to the coffers of the impoverished communes through the arrival of new local tax payers, and the potential economic revitalisation of the area through new custom for local 
traders and artisans. On the other hand, they could also be seen as harbingers of the demise of the peasants' world, the old order that the local population was no longer able to maintain, the precursor of an invasion and the opening of France's borders facilitated by the EU (restrictions on milk quotas etc), largely resisted in this area in the referendum vote on the Maastricht Treaty. The earlier influx of Parisian 'second homers' and néoruraux (would-be rural dwellers) had in Barou's experience revealed a certain prejudice against outsiders, often seen as arrogant and scornful of the local population. How then would the British be received? Would they once again be welcomed as liberators? But first, who were they and what had brought them here?

\section{The Migrants and their motivations: France for Sale?}

The sample taken by Barou involved fifteen couples, almost all of whom had settled here during the period 1989 -1991: this type of migration clearly does not attract single people, unlike Favell's 'Eurostars'. His study did not give any details of the social backgrounds of the respondents, and our interviews established that any attempt to define them in terms of class was not only problematic but unhelpful: only one couple could be easily categorised as wealthy middle-class (he a building surveyor and she an investigative journalist), the others were mainly in professional occupations of some kind, but with relatively modest positions (marketing manager, sales representative, airline stewardess, self-employed tradesman or businessman). Several of the women had not worked outside the home. Some had professional qualifications (agricultural college, teaching certification) and three had 
university degrees, while several had no qualifications beyond school certification.

With regard to their motivations for moving to France, the responses anticipated were largely informed by the literature reviewed above, all of which emphasised what Prado (2000) has called 'le rêve de village' (the village dream). He describes the yearning and nostalgia for times past, and presents a picture of urban exiles trying to recreate in the unspoilt French countryside the rural idyll that eludes them back home where urbanisation has won the day. Barou also describes the British in Normandy in 1992 as being mainly drawn by what they see as the survival of a rural world and local authenticity (space, local produce, local fêtes (festivals) etc).

Our findings however presented a rather different picture for this particular group of migrants, who did not identify strongly with this reason for their move. A majority of respondents were in fact already living in rural areas in the UK, and only one, somewhat atypical couple, would really have fitted the typology of escape from the urban rat-race. One other couple who came to retire explicitly wanted 'to escape Thatcher's Britain.' The main reasons given for coming to France were the fact that low property and land prices made it possible to envisage setting up the sort of enterprise that they could not afford in Britain. For two couples this meant being able to buy a farm (one for sheep, the other for cider apples): both these couples would have stayed in England had they been able to afford to do so. A third farming couple were moved into the area as tenants of a Farmer's Weekly operation, and quite astonishingly, had been given no choice in the decision, with only a few weeks to prepare to leave their previous farm tenancy in Scotland. They had not themselves 
initiated the move (nor even been consulted), and were literally parachuted into the area with three young children and a dog, in the middle of a school term, with only O Level French. One other young couple with children came because the wife wanted to set up a dog-grooming business and could not afford the property prices in her home town on the South Coast. Another young couple (he was running a small business for school photography and she was working with horses) saw the opportunity of cheap property prices to buy a run-down farm in need of restoration, in order to create a new life and a business running gîtes and $\mathrm{B}$ \& $\mathrm{B}$.

None of them had a second home or any other previous connections to the area and bought their property through chance more than design, often rather quickly and in some cases impulsively; the role of French estate agents advertising in British outlets was clearly instrumental here, and should be borne in mind in the context of discussions about the British unsollicited 'invasion' of France (Buller \& Hoggart, 1994). Of those that did not have a specific business idea in mind, but came either for retirement, or for personal reasons, all said that land and property prices had been the main factor in making their decision. For a significant number, personal circumstances (including divorce, redundancy \& retirement) initiated the desire to move, but other destinations had also been considered: Australia, Canada, Greece. This was also true of the only couple who came to this area largely because of friends who had recently settled here.

We can see therefore that high property and land prices in England (nearly all the respondents are English and were all living in England) was the most significant. The proximity of France and the comparatively low prices of land 
and property there thus acted as a strong 'pull' factor for the late-1980s migrants, and for a significant number of respondents in the sample surveyed here, the move to France enabled property and land acquistion to become a reality for the first time. In the Pays d'Auge, it was possible to find a handsome timber-framed manor house with outbuildings in a state of disrepair for the price of a small, very ordinary house in the South of England. The aesthetics of the actual houses bought was clearly a strong factor for some of those interviewed, but by no means for all: many bought the first property they were taken to by the agent.

The discrepancy between our findings and those of Barou could be explained by a number of factors. First, it is possible that he did not seek to identify whether these migrants had come from rural or urban areas. Second, it is possible that the interviewees had by 2007 'forgotten' or re-ordered the heirarchy of reasons that had caused them to migrate; after living in the rural 'idyll' for twenty years, the memory of the stress and pressures of life in the UK at that time might have become less significant as a driving factor in their own mental representation of why they moved, emphasising the practical reasons rather than the 'romanticised' ones which they might have highlighted at the time of Barou's interviews. It is also conceivable that Barou's assumptions regarding the 'rêve de village' over-determined his interpretation of the responses he obtained. Finally, it is possible that the interviewees did not like to emphasise the economic reasons for their move when face to face with a French interviewer: given the strong sense displayed by all these interviewees of the desire to be accepted by the local French population, they 
may have felt that it was rather insensitive to give property prices as the main factor in their decision.

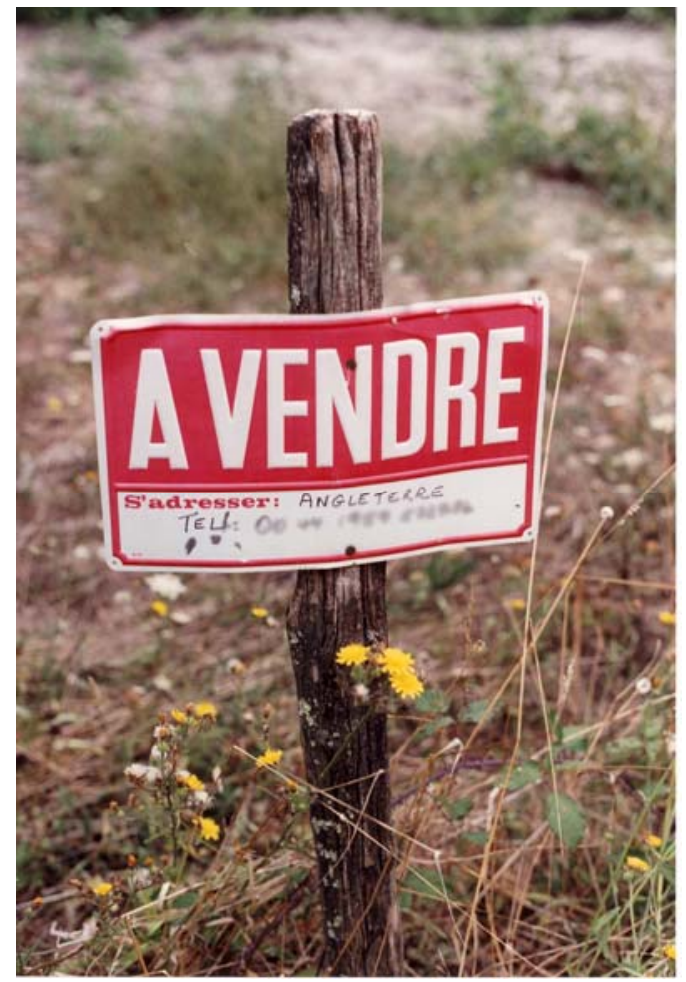

'(France) for Sale - Ring England' (The Dordogne, 2000, @ H. Drake )

\section{Reality bites: language, employment, social life and politics}

Language was seen as a central problem for all of the sample: only three of the interviewees had any practical command of French before moving, the rest said their French was either minimal or 'zero'. None of them however was prepared to let this problem act as an obstacle to their ambition, and all of them took very seriously the need to learn French, though they went about it in very diverse ways: only one couple took formal lessons, the rest simply 'muddled through', for a combination of reasons: time, cost, and availability. All of them had accepted the fact that language was the key to integration, and unlike more recent migrants in the area, they all, apart from one couple, were determined to be accepted by local people and integrate with them. In 
telling their stories, it was clear that all the respondents took for granted the idea that integration was the appropriate model of behaviour, and indeed they measured their own degree of 'success' by what they perceived as their own level of integration, as much as by their ability to earn a living.

The most important factor governing integration was employment: we saw above how a significant majority had moved to France in order to set up businesses of various kinds, so this was critical to their ultimate survival. Within this category we can broadly distinguish two main types of activity: farming and services of various types. The farming group is particularly interesting in ways which go beyond the scope of this paper, but it is also significant because according to Barou's conclusions (1995; 2000), these people were the most successfully integrated because they have implicitly entered into the world of those who constitute the back-bone of the local communities, and have taken on their own concerns regarding the future of farming and the countryside. The couple moved in by Farmer's Weekly were the second couple in the sample to arrive, in 1985 , and their story attracted considerable interest locally; consequently, they were already quite well integrated by the time of Barou's study, when compared to others who had arrived much more recently. Theirs is a fascinating and inspiring story of intraEU migration at its most positive, though in some ways atypical because they did not initiate the move. Now, twenty-two years on, with Farmer's Weekly having withdrawn from the venture in 1987, they are tenants in their own right, he has become a conseiller municipal (local councillor), she teaches English, and the three children have all gone very successfully through the French education system. 
The couple who set up a cider farm have also settled and integrated well, as have their six children, and although they would have initially preferred to stay in the UK if they had been able to finance their venture there, they now see their life in France as infinitely better than what it would have been in the UK, and would not contemplate returning. For the two other couples in this category of Barou's sample, farming was only intended as a part-time activity, and their experience of integration is only partly reflected by this part of their activity.

A second category under the heading of employment brings together various activities defined as the provision of services: renting of gîtes and B \& B for (mainly British) tourists, the teaching of English in local schools or to adults (a growing market in previous years but one which offers no security and relatively low rates of pay), a dog-grooming salon, and various trades people: three carpenters and one general builder specialising in the restoration of old properties for the British property owners (no plumber!). ${ }^{10}$ Some of these activities depended to some degree on British 'consumers' (tourists and second-home owners), but by no means exclusively.

The initial stages of setting up the legal basis for these activities was described by all those doing it independently as 'horrendous', 'a nightmare'. All of the respondents clearly wanted to do everything 'by the book', and were frustrated by the seemingly arcane demands of French bureaucracy, though a

\footnotetext{
${ }^{10}$ Further publications resulting from this field work will develop the problems presented for British tradespeople in having to redefine themselves professionally in order to register with one of the 'Chambres de métier' (occupational/business chamber). There is no broad category that corresponds to the British general builder, and French artisans normally stick to the particular trade in which they are qualified: electrician, plumber, carpenter etc. This situation, as well as the cost of setting up as an artisan in France, has been the cause of many British migrants' resorting to the black economy which has been regularly denounced in the French press.
} 
few were able to enlist the help of an agent to take care of the paperwork for them. It is perhaps worth remembering here and reflecting upon Barou's reference to the entrepreneurial mentality of the British migrants. In those days there was little ready-made literature in English to guide these 'pioneers' (as they see themselves), and they all in some ways had to learn the hard way.

A critical factor in whether or not a venture turned out to be economically viable or not seems to have been the ownership of capital in some form or other, usually produced by the difference between the sale of a property in the UK and the purchase of the property in France. All the businesses ventured into involved considerable investment of both capital and labour which would take several years to start producing income and it was therefore essential to have capital to live off. Those few who did not, fared distinctly less well.

In terms of integration, a successful employment situation could bring about dramatically increased language skills, with a particular emphasis at least initially on the specific occupational vocabularies. Contact with French people in the workplace was also a vital ingredient in facilitating social relations. But although the level of integration was not always closely related to the degree of success of the employment situation, the latter nevertheless had a critical impact on the economic sustainability of the lives of those concerned: although all but one of them (following a divorce) are, perhaps surprisingly, still there, some are living in what the French describe as a 'situation de précarité' (precariousness), with no obvious way out of their predicaments. The youngest of the couples interviewed, one of the first to move there in 1985, have recently decided to sell their property and return to the UK, where 
they will be living with family, since there is little prospect of their being able to re-enter the British property market. She had been teaching English (she had a degree in History and a teaching certificate), but had never obtained a secure full-time contract, and he had tried unsuccessfully to establish himself as a wood-worker. Their final decision to leave was prompted by their son's move into secondary education, which they found extremely disappointing, and by her better prospects of finding a proper teaching job in the UK. One other, quite atypical couple who have lived essentially off capital since their arrival in 1978, describe themselves as 'economic refugees', now unable to.re-enter the British property market.

None of the activities described above, including farming, generates sufficient income on its own, and even those few who have found salaried employment are on low wages that are the norm in the current economic climate dogged by unemployment. Thus all of our sample have a lifestyle that is at best relatively modest, especially when they compare themselves to family and friends back in the UK, or in some cases, to their own previous living standards. However, they mainly own properties whose equivalents in the UK would be way beyond their reach. Besides, they almost unanimously claim not to envy the lifestyle that goes with this higher level of income that has become commonplace in the UK; indeed most expressed strong feelings of rejection of the way of life that has evolved in the UK since their departure, citing avarice, yob culture, the cost of living, traffic levels and the state of health care as reasons for not wanting to return.

A further striking aspect to emerge from the interviewees was their attitude to their move: all but one of the couples were determined to integrate socially, 
and adopted various different strategies to this end. Those who had children were able to take advantage of the contact with other parents and teachers, and by inviting other children to their houses got to speak more French with them. Some emphasised the importance of accepting every opportunity offered by the local commune to participate in events such as the local fête, and even attending all the funerals, and quite a few were consequently invited to join the comité de fêtes (festival committee). Others found no such activities in their local commune, and thus found it harder to establish relations in their immediate vicinity. Some ended up being involved with local activities such as a running club, a dog-training club, and a choir.

Many however felt that due to pressures of work and sometimes also home restoration, they had not had sufficient time to devote to social life. Others felt that there were insufficient activities available locally of interest to them, and those from urban origins bemoaned the fact that it was so far to the nearest cinema or theatre: here were the timid signs of acknowledgement of the dream of the rural idyll referred to by Barou. Likewise, with respect to the French media as a window onto French life and culture, most had started off only watching French TV, but they cited the poor quality of programmes, and the increasing availability of access to British TV as reasons for almost exclusively preferring the latter, though a few still only have French. Many depend heavily on Radio 4 to entertain and keep them in touch with news, not only in the UK but also in France: indeed few were well informed about French current affairs.

All of our 'Brits' were aware of their rights to vote in EU and municipal elections, but only about half had actually exercised this right. A series of 
quite simple questions regarding the political system and election campaign revealed relatively poor knowledge and understanding, even in the cases of three people who in 2001 had become conseillers municipaux one of whom could not name the current Prime Minister. ${ }^{11}$ Those who had distinctly better knowledge were the few that still watch French TV. Thus it emerged that there was no strong correlation between interest in national politics and active local participation. This was justified by those concerned (rather defensively) on the grounds that they were less concerned because they could not vote at national level. For some, this was an important issue and they felt that they should be able to vote nationally in the country of their fiscal residence, rather than according to nationality; one couple felt very strongly that they had been disenfranchised, since British citizens can only retain a postal vote for 15 years, and they did not feel that the right to vote in European and local elections was sufficient compensation. From their perspective, the benefits of EU citizenship do not, apparently, exceed or trump national loyalties.

Significantly, none of the respondents could relate their own venture to the broader framework of Europe or the concept of a European citizenship: even participation in local 'politics' was seen as a purely parochial affair with no wider implications, and one of them thought that it was 'a load of rubbish' to attempt to put it in a European perspective. All three municipal councillors interviewed in this sample had been invited to be included on a list in 2001 (the first time that this was possible for EU citizens). Further research into this

\footnotetext{
${ }^{11}$ Respondents were asked if they knew how many presidential candidates there were, roughly what they stood for, and what parties they represented. They were also asked if they knew roughly how the voting system worked (two rounds with run-off at the second). They were asked to name any previous presidents, and the current Prime Minister. Further questions were only asked if the basic ones were answered appropriately.
} 
specific aspect of how 'Brits' have 'integrated' into their local communities by becoming municipal councillors, carried out across the whole of France in the context of the municipal elections of March 2008, throws more light on whether or not the Normandy sample is typical. ${ }^{12}$

\section{Conclusions: Neighbours or Fellow Citizens?}

Our study has found significant evidence of 'Brits' settling in France in permanent homes, raising families, investing in long-term business undertakings, and integrating to the best of their ability on social, cultural, political and economic levels. Our case-study portrayed a refreshingly positive example of how French and British neighbours, co-workers, 'seniors', farmers and so on co-exist relatively harmoniously.

We saw from the IPPR (Sriskandarajah and Drew, 2007) study that scores of thousands of 'Brits' are moving away from Britain every year and that France is only one of the top ten destinations. Of those that go to France, what seems to count most is the combination of relative proximity (as opposed to the USA or Australia for example), and the price and availablity of the type of property that conforms with the brand 'France' as it appears to them in their 'migratory imagination' (Gervais-Aguer, 2006). Barou and Prado (1995) narrowed down this 'representation' of France to the opportunities that it offers for a different relationship with the countryside; these Brits, they claimed, are France's latest 'neo-rurals', demonstrating that there is life on the land after the decline of traditional agricultural life. This perhaps could in turn lead to the remaking of

\footnotetext{
${ }^{12} \mathrm{~S}$. Collard, paper delivered at the annual conference of the Political Studies Association, University of Swansea, ${ }^{\text {rd }}$ April 2008: 'The French Municipal Elections: Cradle of European Citizenship?'.
} 
new forms of rural communities where what matters most is not nationality but attitudes to work, the land, and one's neighbour.

Our closer look at the Normandy example suggests that migrants' imaginations are not quite as lofty as Barou and Prado might have fondly hoped. Prosaic considerations such as property prices and business opportunities coexist with any nostalgic or fanciful notions of a return to an imagined, idyllic past, especially where mobility (tourism; second homes) becomes migration (settlement); in these respects, France is for sale. British migrants may well be seeking escape routes from the urban density of the UK, but only in so far as this impacts on their capacity to buy property and exercise their professional occupation.

We should also remember that we expect the latest arrivals from Britain to France, dating from the turn of the $21^{\text {st }}$ century to differ from their predecessors as they in turn did from their forerunners. The latest 'wave' of Britons in France appear to be younger still, more professionally active, and to retain tighter links with the UK, even to the point of drawing their salary in the UK and effectively commuting to their home in France - a new model of 'downsizing', perhaps. ${ }^{13}$ Most of our respondents explicitly compared themselves to the more recent British arrivals in the case study region, who they claimed were uninterested in getting to know French people, and who had gravitated into what was called a 'clique', organising local activities in English such as regular 'curry nights' and a quiz night in a local café referred to as the 'pub'. There was clearly much resentment towards these new incomers, perceived as 'having lots of money' (compared to themselves),

\footnotetext{
${ }^{13}$ We thank Christian Lequesne for this observation.
} 
scorning the French, making little or no effort to learn the language, and displaying many of the features of today's Britain that deterred them from contemplating returning to the UK.

In an attempt to find out more about these newest-comers, a small survey was carried out as a follow-up to the main study, using a local 'Anglo-Norman alliance' organisation to identify respondents. Approximately half of them were retired or early-retired, doing things by the book, trying to learn French (but feeling a bit too old to be confident), and to 'integrate', but rarely venturing beyond local fetes and saying hello to their French neighbours. For those just short of statutory retirement age, there were fears they would fall foul of a recent provision barring them from access to French health insurance, thereby removing their residency rights; and some were consequently envisaging a return to the UK. ${ }^{14}$ The other half of the sample were younger, in their 40 s or 50 s, some technically retired but in fact looking to earn a living and, due to minimal language skills, doing it almost exclusively within the British community - the internal market at work. We found evidence of illegal business operations, and of difficulties with getting to grips with the French business and taxation systems; and examples of 'sponging' off French benefits such as the RMI (revenu minimum d'insertion - a form of

\footnotetext{
${ }^{14}$ This rather complex problem relates to the belated transposition in 2006-07 into French law of an EU requirement (EU Directive 2004/38EC; see note 2 above) for non-employed (inactif) or job-seeking EU residents to be covered by comprehensive health insurance in the host country in order to qualify for legal residence. This law was made retrospective and some British residents, usually close to retirement age, found that they were effectively expelled from the French state health insurance scheme, the $\mathrm{CMU}$ (couverture maladie universelle), which raised the serious prospect of an unscheduled return to the UK. Several self-help groups sprang up amongst affected British residents, and in January 2008 the French government amended the legal provisions in question. See http://www.frenchhealthissues.eu/ for context and detailed information by concerned residents; the original legal provision is at http://eur-lex.europa.eu/LexUriServ/site/fr/oj/2004/l 158/l 15820040430fr00770123.pdf. The French Embassy in London has a summary at http://www.ambafrance-uk.org/Update-onMedical-cover-for.html
} 
unemployment benefit designed to encourage the return to work). These cases strongly suggest a degree of 'delusion' on the part of the newer arrivals, whose 'initial imaginings of France are selective'. ${ }^{15}$ We also found friction between this latest wave of British migrants to this corner of Normandy, and those who have been there for some time.

Interestingly, we found some of the new arrivals to be anti-EU, and quite unaware of the fact that the practical benefits of EU free movement that have accrued over time (such as the dropping of the requirement to obtain a French driving licence or carte de séjour - residency permit - for EU nationals) have made their migration an easier experience than for their 'pioneer' predecessors. Guiraudon and Favell (2007) make the point that the 'Eurosceptic British' are indeed 'arguably the most voracious in their using of EU rights to buy property or relocate to other parts of the EU'; whereas Recchi's extensive PIONEUR study (2003), finds to the contrary that EU movers do 'uphold European integration and feel much more strongly European than the general population.'

The broader argument here, following Guiraudon and Favell, is that we need to study 'real people' and their behaviours if we are to grasp the realities of the 'social bases of European integration' alongside the political, economic or institutional dimensions of Europeanisation. Movement, as addressed in our case study, is one such behaviour; as is the network-type activity that 'ordinary' people sometimes engage in, such as town-twinning; or, for Fligstein (2008), the consumption of the European press and 'culture from other countries through films, music, books and television' (207).

\footnotetext{
${ }^{15}$ We thank Michaela Benson (University of Bristol) for this insight.
} 
Findings to date suggest that with increased 'European' behaviours come new social divisions, for example between those who move, and those who stay at home. Recchi (2006: 76) argues that as more people from different social backgrounds move, 'we could even expect the rise of a new politicoidentitarian cleavage based on multicultural mindsets for "movers" vs. monocultural frameworks prevailing amongst "stayers". (...) Originally conceived as an integrative tool across national borders, EU citizenship could thus instead become the basis for emerging forms of social differentiation.' This is a view echoed by Fligstein (2008: 207) for whom 'the least educated, the elderly, the less well-off, and the less skilled remain wedded to the national worldview (...). Their identities remain wedded to the nation.' Our own findings in this respect offer a slightly different perspective, in that they suggest differentiation within the movers themselves, with regard to social, political and cultural identification. Continuing work on the young French working population in London; and on the newest British arrivals in France (not just Normandy) will go some way to fill out our picture in these respects. We can at least expect both the new 'wave' and the next generation of 'old' British migrants in France to tell us more still about the phenomenon of intra-EU migration per se, and in particular the perceived salience and relevance of the EU citizenship framework for the decision to migrate. Our research here has rather suggested that the EU's insiders, at least in this case, take their EU rights for granted in a way that outsiders - TCNs - literally die for. Their movement is instead driven by the same reasons as ever, both universally human, and, relating to the Franco-British relationship: dreams of escape; Romanticism; ambition, opportunity; a notional image of France - 
which in turn appears to be driving some French in the opposite direction; this is movement whose scope is yet to be defined. Unlike the beneficiaries of the EU's Erasmus student mobility scheme, those movers who leave the French experience until later in life are likely to be surprised - pleasantly or otherwise - by the realities of both EU citizenship and the French dream.

8070 words total

\section{References and further reading}

Barou, J., Prado, P. (1995) Les Anglais dans nos campagnes (l'Harmattan). Benson, M. (2007)` « There's more to life » : why the British migrate to rural France', paper delivered at ASA conference 2007 (London Metropolitan University)

Buller, H. and Hoggart, K. (1994) International Counterurbanization. British Migrants in rural France (Avebury).

Campos, C. (2004) 'Hypocrite Français, mon semblable, mon frère' in Bonnaud, L. (ed.) France-Angleterre : Un siècle d'entente cordiale 1904-2004, Paris : I'Harmattan.

Crawford, L. (2007) 'Med-Life Crisis', FT magazine, March 24/25: 19-23.

Favell, A. (2008) Eurostars and Eurocities. Free Movement and Mobility in an Integrating Europe. Oxford: Blackwell

Fligstein, N. (2008) Euroclash. The EU, European Identity and the Future of Europe (Oxford University Press).

Fralon, J. - A. (2006) Au secours, les Anglais nous envahissent! (Editions Michalon)

Geoffroy, C. (2007) 'From « Chamouni » to Chamonix : the British in the Alps' in Geoffroy, C. and Sibley, R. Going Abroad: Travel, Tourism and Migration. Cross-Cultural Perspectives on Mobility. Newcastle: Cambridge Scholars Publishing.

Gervais-Aguer, M. - M (2006) 'Prospective analysis: residential choice and territorial attractiveness.' Cahiers du GRES 30-2006. Available in Engish at http://econpapers.repec.org/paper/grswpegrs/ and in French at http://beagle.u-bordeaux4.fr/portailgres/article.php3?id article=1323

Gervais-Aguer, M. - M. (2004) 'Les fondements de l'attractivité territoriale résidentielle, les enseignements d'une recherche portant sur les résidents britanniques en Aquitaine', Cahiers du GRES, 25-2004. Available at http://econpapers.repec.org/paper/grswpegrs/

Guiraudon, V. and Favell, A. (2007) 'The Sociology of European Integration', Paper presented to the EUSA Conference, Montreal, 2007 (available by browsing the Archive of European Integration at http://www.eustudies.org/). 
Hoggart, K. \& Buller, H. (1994) 'Property Agents as Gatekeepers in British House Purchases in Rural France', Geoforum, Vol.25, No.2, pp.173 187.

HM Government (2005) Controlling our borders : Making migration work for Britain. Five Year Strategy for asylum and immigration (Home Office Cm6472, February).

King, R. et al (2000), Sunset Lives. British Retirement Migration to the Mediterranean (Berg).

Labie, M. (2004) 'L'installation de Britanniques en Poitou-Charentes', Synthèse basée sur le mémoire de DEA Immigratin britannique en Poitou-Charentes, IAAT (Institut Atlantique d'Aménagement des Territoires)

Mallinder, L. (2006), 'Spain bucks trend to lead by example....and accident', European Voice, 9-15 March: 20.

O'Reilly, K. (2000) The British on the Costa del Sol (Routledge).

O'Reilly, K. (2002) 'Britain in Europe/the British in Spain: Exploring Britain's Changing Relationship to the Other through the Attitudes of its Emigrants', Nations and Nationalism Vol. 8, no. 2: 179-93.

Poirier, A. C. (2006) Le modèle anglais. Une illusion française (Alvik Editions)

Puzzo, C. (2007) 'British Migration to the Midi-Pyrenées' in Smallwood, D. (2007) 'The Integration of British Migrants in Aquitaine', in C. Geoffroy and R. Sibley, Going Abroad: Travel, Tourism and Migration. CrossCultural Perspectives on Mobility (Cambridge Scholars Publishing), pp. 110-118.

Recchi, E. (ed.) (2003-06) 'Framework V project 2003-06, PIONEUR: Pioneers of European Integration "From Below": Mobility and the Emergence of European Identity Among National and Foreign Citizens in the EU' (Università di Firenze: http://www.obets.ua.es/pioneur

Recchi, E. (2006) 'From Migrants to Movers : Citizenship and Mobility in the European Union', in M. P. Smith and A. Favell (eds.) The Human Face of Global Mobility. International Highly Skilled Migration in Europe, North America and the Asia-Pacific, New Brunswick: Transaction, pp. 53-77. John Murray Publishers.

Ring. J. (2000) How the English Made the Alps, John Murray

Smallwood, D. (2007) 'The Integration of British Migrants in Aquitaine', in C. Geoffroy and R. Sibley, Going Abroad: Travel, Tourism and Migration. Cross-Cultural Perspectives on Mobility (Cambridge Scholars Publishing), pp. 119-131.

Sriskandarajah, D., C. Drew, (2006) Brits Abroad. Mapping the Scale and Nature of British Emigration (IPPR).

Tindall, G. (2004), 'Tourist into Resident' in R. Mayne et al (eds.), CrossChannel Currents. 100 years of the Entente cordiale (Routledge, in association with the Franco-British Council), pp. 275-77.

Tombs, R., I. Tombs (2006) That Sweet Enemy. The French and the British from the Sun King to the Present (William Heinemann) 